\title{
Roles of plant hormones and anti-apoptosis genes during drought stress in rice (Oryza sativa L.)
}

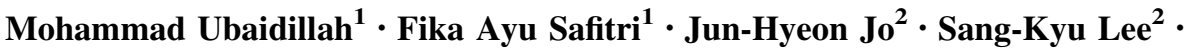 \\ Adil Hussain ${ }^{1,3} \cdot$ Bong-Gyu Mun ${ }^{1}$ - Il Kyung Chung ${ }^{4}$ Byung-Wook Yun ${ }^{1}$. \\ Kyung-Min Kim ${ }^{1}$
}

Received: 13 September 2016/ Accepted: 3 November 2016/Published online: 17 November 2016

(c) The Author(s) 2016. This article is published with open access at Springerlink.com

\begin{abstract}
We previously identified the rice (Oryza sativa) senescence-associated gene $O s S A P$ which encodes a highly conserved protein involved in anti-apoptotic activity. This novel Bax suppressor-related gene regulates tolerance to multiple stresses in yeast. Here, we show the effects of drought stress on leaf and root tissues of plants over-expressing OSSAP in relation to the levels of phytohormones, abscisic acid (ABA), jasmonic acid (JA), indole-3-carboxylic acid (ICA), gibberellic acid $\left(\mathrm{GA}_{3}\right)$, and zeatin. Results showed that rice plants over-expressing $S A P$ were tolerant to drought stress compared to wild type and the plants over-expressing $A t B I-1$, which is a homolog of the human Bax inhibitor-1 in Arabidopsis. ABA and JA levels in $O S S A P$ and $A t B I-1$ transgenic plants consistently increased up to at least 3 days after drought treatment, whereas lower $\mathrm{GA}_{3}$ levels were recorded during early
\end{abstract}

Electronic supplementary material The online version of this article (doi:10.1007/s13205-016-0564-x) contains supplementary material, which is available to authorized users.

Byung-Wook Yun

bwyun@knu.ac.kr

Kyung-Min Kim

kkm@knu.ac.kr

1 Division of Plant Biosciences, School of Applied Biosciences, College of Agriculture and Life Science, Kyungpook National University, Daegu 41566, Korea

2 Research Institute of Pharmaceutical Sciences, College of Pharmacy, Kyungpook National University, Daegu 41566, Korea

3 Department of Agriculture, Abdul Wali Khan University, Mardan, Pakistan

4 Department of Biotechnology, Catholic University of Daegu, Gyeongsan-Si, Gyeongbuk 38430, Korea drought period. Comparison between control and transgenic plants overexpressing anti-apoptosis genes $O S S A P$ and $A t B I-1$ resulted in different patterns of hormone levels, indicating that these genes are involved in the plant responses to drought stress and present an opportunity for further study on drought stress tolerance in rice and other plant species.

Keywords Anti-apoptosis genes · AtBI-1 - Drought stress · OsSAP · Plant hormone · Rice

\section{Introduction}

Different abiotic stresses caused by extremes of temperature, salinity, water and nutrient shortage have always been the key limiting factors for agricultural production. These are considered to play a major role in the deterioration of agricultural ecosystems around the world, causing an average 50\% reduction in crop yield (Boyer 1982). Most often abiotic stresses mediate early responses during signal transduction and adaptive responses (Kawai-Yamada et al. 2005b). At cellular level, various abiotic stresses lead to a plethora of physiological and biomolecular changes that negatively affect plant productivity (Wang et al. 2001). These changes are mainly the outcome of the overall plant responses aimed at tolerating the stress and prioritizing the most important physiological processes. Among the different abiotic stresses, drought is one of the oldest and longest studied type of stress and perhaps also the most damaging as it affects plants throughout the world, especially in the rainfed areas (Flowers 2004; Zhang et al. 2006; Godfray et al. 2010; Tester and Langridge 2010). The Pro-apoptotic factor BCL2-associated X protein (Bax) plays a central role in 
regulating PCD (Kroemer 1997) and was first identified as a member of the BCL-2 family of proteins (Oltvai et al. 1993). In mammals, the members of this family are often found as hetero- or homodimers. For example, Bax and BCL2 form a heterodimer which acts as apoptotic activator. Under normal conditions, Bax proteins are located in the cytosol. However, after the initiation of apoptotic signaling Bax proteins undergo conformational changes and are directed to the membranes of different organelles specially the mitochondria (Hsu et al. 1997; Gross et al. 1998; Nechushtan et al. 1999). At the mitochondrial membrane, Bax interacts with and promotes the opening of mitochondrial voltage-dependent anion channel (VDAC) (Shi et al. 2003). This increases the permeability of the mitochondrial outer membranes resulting in caspase activation and the release of cytochrome $\mathrm{c}$ and other proapoptotic factors (Weng et al. 2005). In plants, the intentional execution of cells in plants also called programmed cell death (PCD) or the hypersensitive response (HR) is a type of defense response that is very important for plant survival, development and adaptation under adverse conditions (Huckelhoven 2004). Interestingly, functional similarity between animal and plant apoptotic machinery also exists. Though Bax genes are yet to be identified in plants, genes that exhibit Bax-like lethality have been found in Arabidopsis (Kawai-Yamada et al. 2001, 2005a). Expression of animal Bax proteins in yeast induced cell death (Sato et al. 1994; Hanada et al. 1995; Lacomme and Cruz 1999; Kawai-Yamada et al. 2001). Similar mechanisms of PCD have also been found in bacteria (Wang and Bayles 2013). This shows that Bax genes and/or Bax-like functionality may be highly conserved across the different kingdoms. Furthermore, homologs of the mammalian Bax inhibitor-1 (BI-1) have also been found in Arabidopsis (Kawai-Yamada et al. 2004), tobacco [Nicotiana sp.; (Wang et al. 2001)], and barley [Hordeum sp.; (Eichmann et al. 2004)]. Expression of AtBI-1 suppresses mammalian Bax-induced cell death in plants and yeast (Sanchez et al. 2000). BI-I from pepper conferred resistance to multiple abiotic stresses when expressed in tobacco (Isbat et al. 2009), showing that BI-1 might also play a role in the adaptive responses of plants to abiotic stresses and at the same time keep a check on programmed cell death as both abiotic stresses and PCD are considered detrimental factors in plant development. Both apoptosis in animals and PCD in plants are highly complex processes and the underlying molecular mechanisms are still being investigated. Though Bax-BI-1 interaction presents an intelligent mechanism for regulation/control of PCD in plants, there are many other factors that play important roles in programming cells for intentional suicide. Various aspects of PCD or HR in plants have been elucidated by a significant amount of scientific research available in the literature.
Different cellular components/compounds play important roles in PCD such as metal complexes (ArasimowiczJelonek et al. 2012; Samuilov et al. 2014; Tewari et al. 2015), reactive oxygen species (ROS) (Foyer 2007a, b; Gadjev et al. 2008; Petrov et al. 2015), nitric oxide (NO) (Arasimowicz-Jelonek et al. 2012), various enzymes such as Cytochrome c (De la Rosa et al. 2015; Gonzalez-Arzola et al. 2015) and caspases (Piszczek and Gutman 2007; Siczek and Mostowska 2012), various lipids and lipid derivatives (Biswas and Mano 2015), secondary metabolites, e.g., chitosan (Vasil'ev et al. 2009), ascorbate (Locato et al. 2009) and many others. Similarly genes that play important roles in regulating PCD in plants encode transcription factors (Yang et al. 2014), antioxidant enzymes (Solovieva et al. 2013), calmodulin-binding proteins, e.g., AtBAG6 (Kang et al. 2006), calcium ion transports, e.g., Arabidopsis PPF1 (Li et al. 2004), housekeeping genes, e.g., actin (Franklin-Tong and Gourlay 2008) and other proteins like the programmed cell death 4 (PDCD4) proteins (Cheng et al. 2013), Fas-associated Factor 1 Ortholog (CaFAF1) proteins (Kim et al. 2009), and several others. Some of the important and/or significant molecular mechanisms involved in regulation of PCD in plants have been comprehensively reviewed by Rantong and Gunawardena (2015), Ma and Berkowitz (2011), Kacprzyk et al. (2011) and Reape et al. (2008). Evidence of programmed cell death during senescence also exists (Zhou et al. 2005; Del Duca et al. 2014). An important but largely un-explored research avenue is the connection between PCD and various plant hormones. Only limited information is available in the literature about the role of plant hormones in PCD for example ethylene due to its role in senescence (Trobacher 2009), and cytokinin (Kunikowska et al. 2013). Plant hormones comprise a very important part of the plant response continuum against biotic and abiotic stresses (Davies 1987, 1995) as well as of the growth and development machinery. Plant hormones play key roles in reprogramming complex physiological processes and stress adaptive strategies (Golldack et al. 2013). Most plant hormones have signature biological functions as well as additive, antagonistic and/or synergistic effects in combination with other hormones and signaling molecules (Aloni et al. 2006), hence making the identification of specific hormone networks much more complex and difficult. We previously identified the rice gene encoding Senescence-Associated Protein $(O S S A P)$ exhibiting anti-apoptotic activity under salt stress (Ubaidillah et al. 2015). In this study, we evaluated the PCD-suppressing activity of OsSAP and the Arabidopsis Bax Inhibitor homolog AtBI-1 by over-expression of these genes inrice (japonica cv. Ilmi and Ilpum) under drought conditions and in relation to different plant hormones. 


\section{Materials and methods}

\section{Plasmid construction for $O S S A P$ and $A t B I-1$}

OsSAP and AtBI-1 were cloned in pBIN19 binary vector between SalI and NcoI. Open reading frames were PCR amplified using specific primers containing flanking adapter sequences for SalI and NcoI. PCR product and pBIN19 were digested with SalI and NcoI restriction enzymes (TaKaRa, Japan) and then ligated using T4 DNA ligase (Promega). All steps were performed according to the manufacturer's instructions. The pBIN19-CaMV35S::Os$S A P:: G F P$ and pBIN19-CaMV35S::AtBI-1::GFP constructs thus generated were transformed into Agrobacterium tumefaciens strain LBA4404 after sequence confirmation (Supplementary Fig. 1).

\section{Agrobacterium-mediated transformation}

The pNIB19-CaMV35S::OsSAP::GFP and pBIN19CaMV35S::AtBI-1::GFP constructs were transformed into rice through tissue culture technique. Briefly, calli of Oryza sativa L. ssp. japonica cv. Ilmi and Ilpum were produced by seed culture in Murashige and Skoog induction medium (4.14 g/L MS vitamin powder, $30 \mathrm{~g} / \mathrm{L}$ sucrose, $0.3 \mathrm{~g} / \mathrm{L}$ casein hydrolysate, and $50 \mathrm{mg} / \mathrm{L} 2,4-\mathrm{D}, \mathrm{pH} 5.6$ ) at $28^{\circ} \mathrm{C}$ under continuous dark for 30 days. Agrobacteria containing both the constructs were grown in LB medium containing $20 \mathrm{mg} / \mathrm{L}$ spectinomycin, $50 \mathrm{mg} / \mathrm{L}$ kanamycin, and $25 \mathrm{mg} / \mathrm{L}$ rifampicin at $28{ }^{\circ} \mathrm{C}$ until $\mathrm{O}^{\circ} \mathrm{D}_{600}=1$. The cultured Agrobacteria were then pelleted by centrifugation at $3000 \mathrm{rpm}$ for $10 \mathrm{~min}$. The resulting pellet was re-suspended in an equal volume of MS-Acetosyringone (MSAS) medium $(20 \mathrm{~g} / \mathrm{L}$ sucrose, $10 \mathrm{~g} / \mathrm{L}$ glucose, $0.3 \mathrm{~g} / \mathrm{L}$ casein hydrolysate, $100 \mu \mathrm{M}$ acetosyringone, $\mathrm{pH}$ 5.6). These bacteria were then co-incubated with the rice calli for $1 \mathrm{~h}$ at $28{ }^{\circ} \mathrm{C}$ in a shaking incubator at $180 \mathrm{rpm}$. After draining out the Agrobacterium suspension, the calli were kept on sterile tissue papers and then transferred to MS cocultivation medium (MS callus induction medium containing $50 \mathrm{mg} / \mathrm{L}, 2.4-\mathrm{D}$ and $100 \mu \mathrm{M}$ acetosyringone) and incubated at $28{ }^{\circ} \mathrm{C}$ for 3 days in dark. Then, the calli were washed with distilled water twice and $250 \mathrm{mg} / \mathrm{L}$ carbenicillin solution. Extra solutions were dried on sterile tissue papers and incubated on MS elimination medium (MS callus induction medium containing $250 \mathrm{mg} / \mathrm{L}$ carbenicillin) at $32.5{ }^{\circ} \mathrm{C}$ for 10 days in dark. Actively growing calli were transferred to selection and regeneration medium MS basal medium supplemented with $1 \mathrm{mg} / \mathrm{L}$ 1-naphthaleneacetic acid, $3 \mathrm{mg} / \mathrm{L}$ 6-benzyl adenine, $3 \mathrm{~g} / \mathrm{L}$ casein hydrolysate, $30 \mathrm{~g} / \mathrm{L}$ maltose, $250 \mathrm{mg} / \mathrm{L}$ carbenicillin, and $40 \mathrm{mg} / \mathrm{L}$ geneticin) and incubated under long day light conditions ( $16 \mathrm{~h}$ light and $8 \mathrm{~h}$ dark) at $28^{\circ} \mathrm{C}$ with continuous sub-culturing on the same medium after 15 days until shoot generation. Regenerated shoots were transferred to rooting medium (half-strength plain MS medium supplemented with $50 \mathrm{mg} / \mathrm{L}$ geneticin). Rooted plants were then transferred to soil after 4 weeks. Subsequently, wellestablished hardened plants were transferred to fresh soil in pots in green house. All transgenic plants were genotyped for the presence of transgene using PCR.

\section{Polymerase chain reaction $(\mathrm{PCR})$ analysis}

Genomic DNA was extracted from leaf tissue of the transgenic plants using DNeasy Plant Mini Kit (QIAGEN, Germany) following manufacturer's instructions. The primers used for amplifying a $420 \mathrm{bp}$ fragment of $O S S A P$ gene were: $5^{\prime}$ CCTTTCCATTTGGGAATCCAGCC- $3^{\prime}$ and $5^{\prime}$ GCCCAGGGTTTCACCAGGAAGTT- $3^{\prime}$. The PCR conditions used were: $94^{\circ} \mathrm{C}$ for $10 \mathrm{~min}$ followed by 45 cycles of $94{ }^{\circ} \mathrm{C}$ for $30 \mathrm{~s}, 57^{\circ} \mathrm{C}$ for $30 \mathrm{~s}, 72^{\circ} \mathrm{C}$ for $1 \mathrm{~min}$, and a final extension at $72{ }^{\circ} \mathrm{C}$ for $5 \mathrm{~min}$. For confirmation of $A t B I-1$ transgene, the primers used were: 5'-ATGGATGCGTTCTCTTCCTT- $3^{\prime}$ and 5'-CAGCCCCTCAGTTTCTCCTT- $3^{\prime}$, which generated a 720 bp fragment. The PCR conditions used were: $94^{\circ} \mathrm{C}$ for $10 \mathrm{~min}$ followed by 45 cycles of $94{ }^{\circ} \mathrm{C}$ for $30 \mathrm{~s}, 55.5^{\circ} \mathrm{C}$ for $30 \mathrm{~s}, 72{ }^{\circ} \mathrm{C}$ for $1 \mathrm{~min}$, and a final extension at $72{ }^{\circ} \mathrm{C}$ for $5 \mathrm{~min}$. The PCR products were visualized after electrophoresis on $1 \%$ agarose gels.

\section{Flanking sequence tags (FSTs) analysis}

Genomic DNA from T1 lines was digested with $B f a \mathrm{I}$ (NEB, UK) for $5 \mathrm{~h}$ at $37^{\circ} \mathrm{C}$. Next 5-10 $\mu$ l of the restriction digestion reaction was used for ligation of 12.5 pmol $B f a \mathrm{I}$ adapter sequences (ADP1; 5'-CTAATACGACTCACTA TAGGGCTCGAGCGGCCGGGCAGGT- $3^{\prime}$, and ADP2; $5^{\prime}$-TAACCTGCCCAA- $3^{\prime}$ ) to the digested fragments using T4 DNA ligase (NEB, UK) for $11 \mathrm{~h}$ at $14{ }^{\circ} \mathrm{C}$. Linear amplification reaction contained whole $B f a I$ digest, $200 \mathrm{nM}$ primers AP1 (5'-GGATCCTAATACGACTC ACTATAGGGC- $3^{\prime}$ ), pBIN-TDNA1 (5'-CAATCAGCT GTTGCCCGTCT-3') for right border, pBIN-TDNA3 (5'CCAAACGTAAAACGGCTTGT-3 ${ }^{\prime}$ ) for left border, dNTPs $(250 \mu \mathrm{M}$ each), and Taq DNA polymerase (TaKaRa, Japan). Amplification was performed using the following parameters. Initial denaturation at $94{ }^{\circ} \mathrm{C}$ for 2 min, 30 cycles of $94{ }^{\circ} \mathrm{C}$ for $35 \mathrm{~s}$, annealing at $64^{\circ} \mathrm{C}$ for $1 \mathrm{~min}$, extension at $73{ }^{\circ} \mathrm{C}$ for $1.5 \mathrm{~min}$, and final extension at $73{ }^{\circ} \mathrm{C}$ for $3 \mathrm{~min}$. Subsequently, $1 \mu \mathrm{L}$ of the first amplification reaction was used as a template for the second PCR with a reaction mixture containing $\mathrm{AP} 2$ (5'TATAGGGCTCGAGCGGC-3'), nested T-DNA primers 
pBIN-TDNA2 for right border (5'-GTCTCACTGGTGAAAAGAAA-3' $3^{\prime}$ pBIN-TDNA4 for left border (5'GGTCATAACGTGACTCCCTTA-3'), and adapter primers. All the products so obtained were sequenced and analyzed through BLASTN search against binary vector sequences and plant genomic sequences.

\section{Analysis of drought tolerance}

Sterilized and chilled wild type and $\mathrm{T}_{1}$ transgenic seeds were sown in plastic trays in a greenhouse under long day light conditions at $30 \pm 2{ }^{\circ} \mathrm{C}$. Standard agronomic practices were followed for irrigation and fertilizer requirements, etc. When the plants were 5 weeks old, drought stress was imposed by decanting all the water from the trays to speed up dehydration. Further irrigation was stopped for 4 days and sample collection was made on 3 and 4 days after withholding water for plant hormone measurement, because prolonged drought stress more than 5 days under our condition caused completed death of plants. Therefore, data on survival rate were recorded with at least 50 plants of each genotype tested. Leaf and root samples were collected 3 and 4 days post-treatment in liquid nitrogen and stored at $-80{ }^{\circ} \mathrm{C}$.

\section{RNA extraction and cDNA synthesis}

Total RNA was isolated from leaf and root tissues using RNeasy Plant Mini Kit (QIAGEN, Germany) following the manufacturer's protocol. Briefly, $100 \mathrm{mg}$ triplicate samples were taken from control and drought-treated WT, OsSAP and AtBI-1. The samples were crushed in liquid nitrogen and vigorously re-suspended in a microcentrifuge tube using $450 \mu \mathrm{L}$ buffer RLT on a vortex, followed by incubation at $56^{\circ} \mathrm{C}$ for $3 \mathrm{~min}$. The lysate was then transferred to QIA shredder spin column and centrifuged at full speed on a bench-top centrifuge for $2 \mathrm{~min}$. The supernatant of the flow-through was then transferred to a new microcentrifuge tube. Half volume $99 \%$ ethanol was added to the tubes and mixed immediately. All the contents were then transferred to RNeasy spin columns and centrifuged for $15 \mathrm{~s}$ at 10,000 rpm. After discarding the flow-through, the columns were washed with $700 \mu \mathrm{L}$ buffer RW1 and then washed with $500 \mu \mathrm{L}$ buffer RPE. After a final centrifugation for $1 \mathrm{~min}$ to remove the remaining liquid, the total RNA was eluted in $30 \mu \mathrm{L}$ RNase-free water. cDNA was synthesized from $1 \mu \mathrm{g}$ total RNA using qPCRBIO cDNA synthesis kit according to the manufacturer's instructions. The reaction mixture $[5 \times$ synthesis mix $(4 \mu \mathrm{L})$, reverse transcriptase $(1 \mu \mathrm{L})$ and nuclease-free water up to $20 \mu \mathrm{L}$ ] was incubated at $27{ }^{\circ} \mathrm{C}$ for $10 \mathrm{~min}$ and $42{ }^{\circ} \mathrm{C}$ for $30 \mathrm{~min}$ before final inactivation at $85{ }^{\circ} \mathrm{C}$ for $10 \mathrm{~min}$.

\section{Quantitative measurement of major plant hormones}

Plant hormones like abscisic acid (ABA), indole-3 carboxylic acid (ICA), jasmonic acid (JA), gibberellic acid (GA) and zeatin content were measured according to (Ubaidillah et al. 2015). Briefly, a triplicate of fresh plant tissue $(200 \mathrm{mg}$ ) was prepared in batches for the measurement all plant hormones above and was ground in liquid nitrogen to fine powder with mortar and pestle. The tissue powder was then dissolved in $100 \mu \mathrm{L}$ of specific working solution of internal standard and $700 \mu \mathrm{L}$ of extraction solvent (Ubaidillah et al. 2015). The resulting extracts were then through a series of centrifugation and purification step with a mixture of iso-propanol/ $\mathrm{H}_{2} \mathrm{O}$ /concentrated $\mathrm{HCl}$ (2:1:0.002, v/v/v). The final concentration was re-dissolved in $100 \mu \mathrm{L}$ methanol and a half was subjected to ESI-triple quadrupole mass spectrometer (HPLC-ESI-MS/MS, Applied Biosystems, USA) equipped with a reverse-phase C18 Gemini column $(150 \times 2.00 \mathrm{~mm}, 5-\mu \mathrm{m}$ particle size, Phenomenex, USA).

\section{Statistical analysis}

All experiments were replicated at least three times, and all data were analyzed using the SPSS program (IBMSPSS Statistics, version22, NC).

\section{Results}

To evaluate the PCD-suppressing activity of OsSAP and $A t B I-1$ in relation to drought stress tolerance in rice and determine their PCD inhibition mechanism, we expressed OsSAP and AtBI-1 cloned under the control of the CaMV35S promoter in rice. In this first generation $\left(T_{0}\right)$, we obtained more than 100 transformants for both the cultivars Ilmi and Ilpum. All these transformants were resistant to kanamycin. All the plants of $T_{0}$ generation were genotyped through PCR. After genotyping, 5 independent lines (2 in Ilmi and 3 in Ilpum) containing CaMV35S::OsSAP and 20 independent lines (12 in Ilmi and 8 in Ilpum) containing CaMV35S::AtBI-1 were confirmed as proper transgenic lines. No phenotypic differences were observed among the lines expressing either of the transgenes. After the T-DNA flanking region sequencing, $T_{0}$ lines expressing a single intergenic copy of either of the transgenes were sown again to harvest $T_{1}$ seeds for further studies.

\section{Response of anti-apoptosis genes to drought stress}

T1 transgenic lines over-expressing OsSAP and AtBI-1 were tested for their response to drought stress. Both types of transgenic lines were resistant to drought stress 


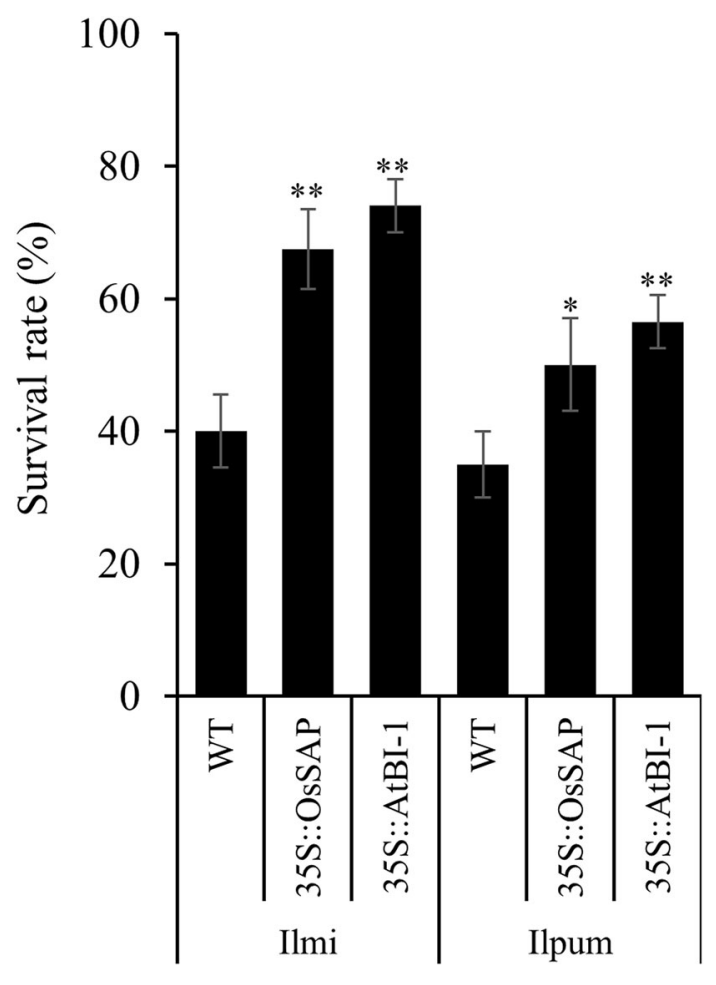

Fig. 1 Tolerance of the OsSAP and AtBI-1 transformants to drought stress compared with control. $A$, phenotype after drought stress in transgenic rice overexpressing $O S S A P$ and $A t B I-1$. L, Ilmi; $P$, Ilpum; $T_{1}-L O, O S S A P \mathrm{~T}_{1}$ transformants in Ilmi; $T_{1}-P O$, OsSAP $\mathrm{T}_{1}$ transformants n Ilpum; $T_{1}-L A, A t B I-1 \mathrm{~T}_{1}$ transformants in Ilmi; $T_{1}-P A$, AtBI-1 $\mathrm{T}_{1}$ transformants in Ilpum. *, **Significant at 5 and $1 \%$ levels, respectively

compared to wild type (WT) plants as shown by significantly higher survival rates. Withering and leaf shrinking were observed in WT plants after 4 days of drought stress. After 5 days, the survival rate of both the transgenic lines in both cultivars was significantly higher than WT plants (Fig. 1). Survival rates were measured after 5 days and are represented by mean values for at least 50 transformants. Furthermore, AtBI-1 over-expression increased the survival rates of plants from both the cultivars compared to OSSAP and WT plants. However, in general the survival rates of the cultivar Ilmi were approx. 20\% higher than those of Ilmi indicating a higher endogenous tolerance to drought stress compared to the Ilpum cultivar. The survival rate of OsSAP-Ilmi transformants was $10 \%$ higher than that of WT-Ilmi plants. Similarly, the survival rate of OSSAPIlpum transformants was $15 \%$ higher than that of WTIlpum (Fig. 1).

The transgenic lines expressing either of the transgenes were resistant to drought stress. This prompted us to measure the contents of various plant hormones, such as abscisic acid (ABA), jasmonic acid (JA), gibberellic acid $\left(\mathrm{GA}_{3}\right)$, zeatin, and indole 3 carboxylic acid (ICA) in the leaf and root tissues before and after drought stress treatment. Results showed that OsSAP and AtBI-1 over-expression significantly increased the ABA contents in the leaves and roots of both the cultivars under study for up to 4 days after drought stress induction (Fig. 2).

OsSAP and AtBI-1 overexpression significantly increased JA levels in both rice cultivars, especially in the leaves after 3 days of drought stress induction. However, JA levels dropped dramatically on after 4 days of drought stress induction (Fig. 3). JA levels in control Ilmi and Ilpum plants increased after 3 days in both leaf and root tissues, but decreased after 4 days of drought stress treatment. Different patterns were observed in Ilmi transgenic lines overexpressing $O S S A P$ and $A t B I-1$. The JA level in leaf tissue after 3 days of treatment increased dramatically by approximately fivefold compared to the JA level before treatment. In root tissue, the level increased approximately threefold after drought stress treatment, whereas in control rice only a slight increase of JA levels was noted. The level of JA in Ilpum transgenic lines overexpressing $O S S A P$ and $A t B I-1$ also increased, although to a lesser degree. The level of JA in Ilpum transgenic lines overexpressing OsSAP and AtBI-1 increased by 3 - and 2-fold in leaf and root tissue, respectively, after 3 days of drought stress. JA level decreased after 4 days of treatment in all genotypes and there was no difference between transgenic lines and control rice plants (Fig. 3).

$\mathrm{GA}_{3}$ levels were significantly lower in all the wild type and transgenic lines under normal conditions. However, these levels significantly increased after 3 and 4 days of drought stress induction in both the leaves and roots of Ilmi and Ilpum plants (Fig. 4). $\mathrm{GA}_{3}$ levels in leaf and root tissues of the transgenic plants were $2-7$ fold higher than those of the control plants, although this level was not maintained throughout the prolonged drought stress conditions. $\mathrm{GA}_{3}$ levels in Ilmi and Ilpum transgenic lines overexpressing AtBI-1 were similar to those in OsSAP transgenic lines (Fig. 4).

Estimation of the cytokinin zeatin levels under drought conditions revealed increased levels of zeatin in both the control and transgenic lines. A significant increase in zeatin levels was observed in the leaf and root tissues after 3 and 4 days of drought stress induction in all the transgenic lines of ilmi and ilpum (Fig. 5). Prolonged drought stress increased zeatin levels in all genotypes.

The levels of auxin ICA in WT and transgenic lines were measured after drought stress induction. The level of ICA in control rice and transformants did not show a notable difference. Auxin ICA levels in control plants dramatically decreased in leaf and root tissue of all the genotypes after 3 days of drought stress and continued up to 4 days (Fig. 6). 
Fig. 2 Abscisic acid (ABA) level in transformants compared with non-transformant controls under drought conditions overtime. Mean values $\pm \mathrm{SE}$ are given. LL: control Ilmi-leaf, $L R$, control Ilmi-leaf; $P L$, control Ilpum-leaf; $P R$, control Ilpum-root; $L O L, O s S A P$ Ilmi transformants-leaf; $L O R$, OsSAP Ilmi transformants-root; $P O L$, OsSAP Ilpum transformants-leaf; $P O R$, $O s S A P$ Ilpum transformantsroot; $L A L, A t B I-1$ Ilmi transformants-leaf; LAR, AtBI-1 Ilmi transformants-root; $P A L$, AtBI-1 Ilpum transformantsleaf; PAR, AtBI-1 Ilpum transformants-root. *

**Significant at 5 and $1 \%$ levels, respectively
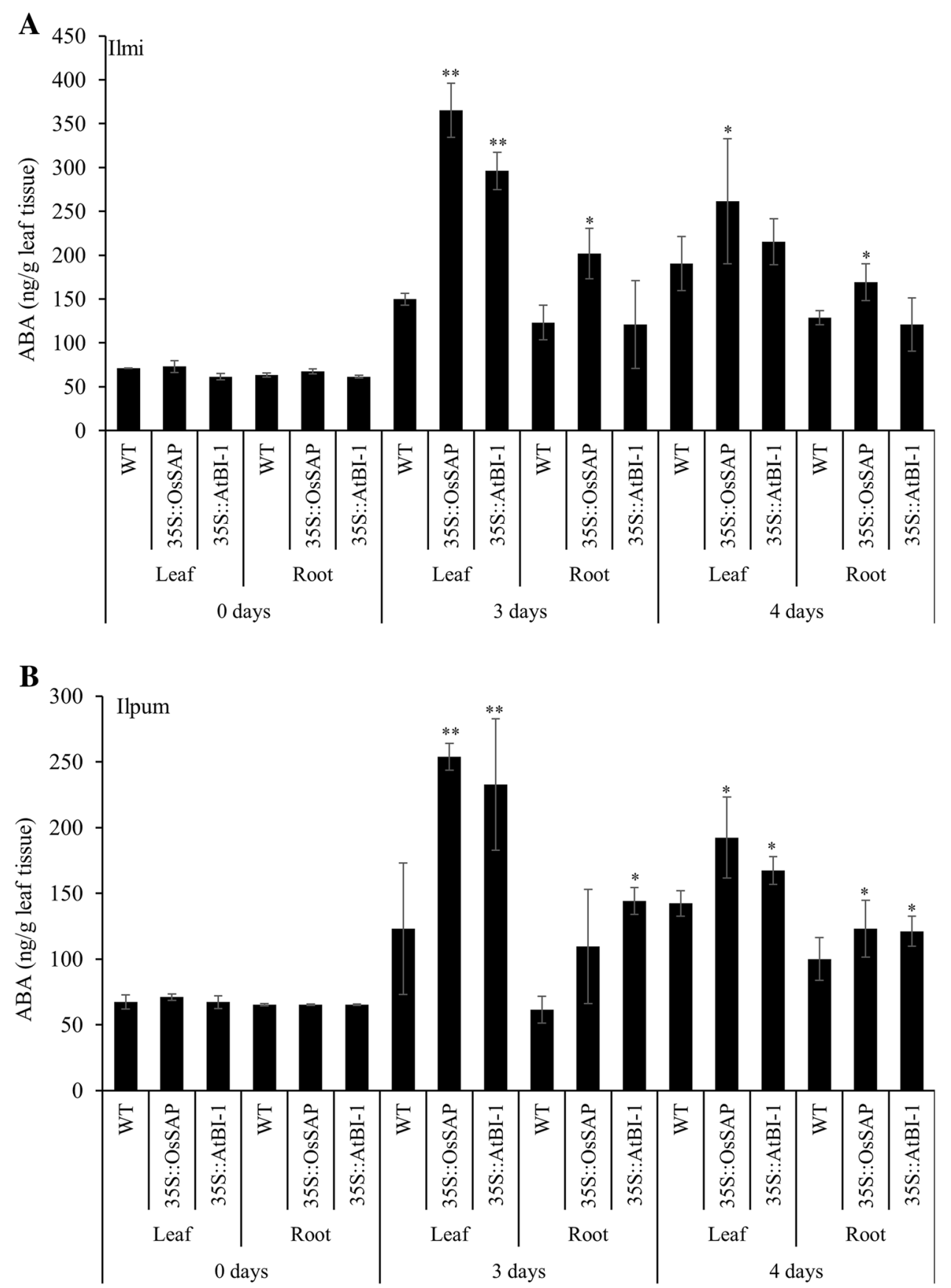

\section{Discussion}

Previously we reported that the over-expression of the antiapoptotic genes $O S S A P$ and AtBI-1 in rice promoted salt tolerance (Ubaidillah et al. 2015). In this study, we investigated the role of these anti-apoptotic genes in drought stress tolerance and biosynthesis and signaling of various plant hormones which are involved in the regulation of multiple biotic and abiotic stresses. We constitutively over-expressed both the genes under the control of CaMV35S promoter. Overall, the over-expression of both the genes promoted drought tolerance of rice cultivars Ilmi and Ilpum. Survival rates of plants after drought stress treatment were also higher for the transgenic lines than WT plants. Involvement of $B I-1$ related genes inducible by various abiotic and redox stress conditions has been reported in the literature (Watanabe and Lam 2008).

OSSAP which encodes senescence-associated protein might be related to the Bax inhibitor gene because the plant $B I-1$ genes are also expressed in diverse tissue types and their expression levels are enhanced during aging and senescence (Eichmann et al. 2004). This study shows that 
Fig. 3 Jasmonic acid (JA) level in transformants compared with non-transformant controls under different drought conditions. Mean values $\pm \mathrm{SE}$ are given. $L L$, control Ilmi-leaf; $L R$, control Ilmi-leaf; $P L$, control Ilpum-leaf; $P R$, control Ilpumroot; $L O L, O S S A P$ Ilmi transformants-leaf; $L O R$, OsSAP Ilmi transformants-root; $P O L$, OsSAP Ilpum transformants-leaf; $P O R$, OsSAP Ilpum transformantsroot; $L A L, A t B I-1$ Ilmi transformants-leaf; LAR, AtBI-1 Ilmi transformants-root; $P A L$, AtBI-1 Ilpum transformantsleaf; PAR, AtBI-1 Ilpum transformants-root. *,

**Significant at 5 and $1 \%$ levels, respectively
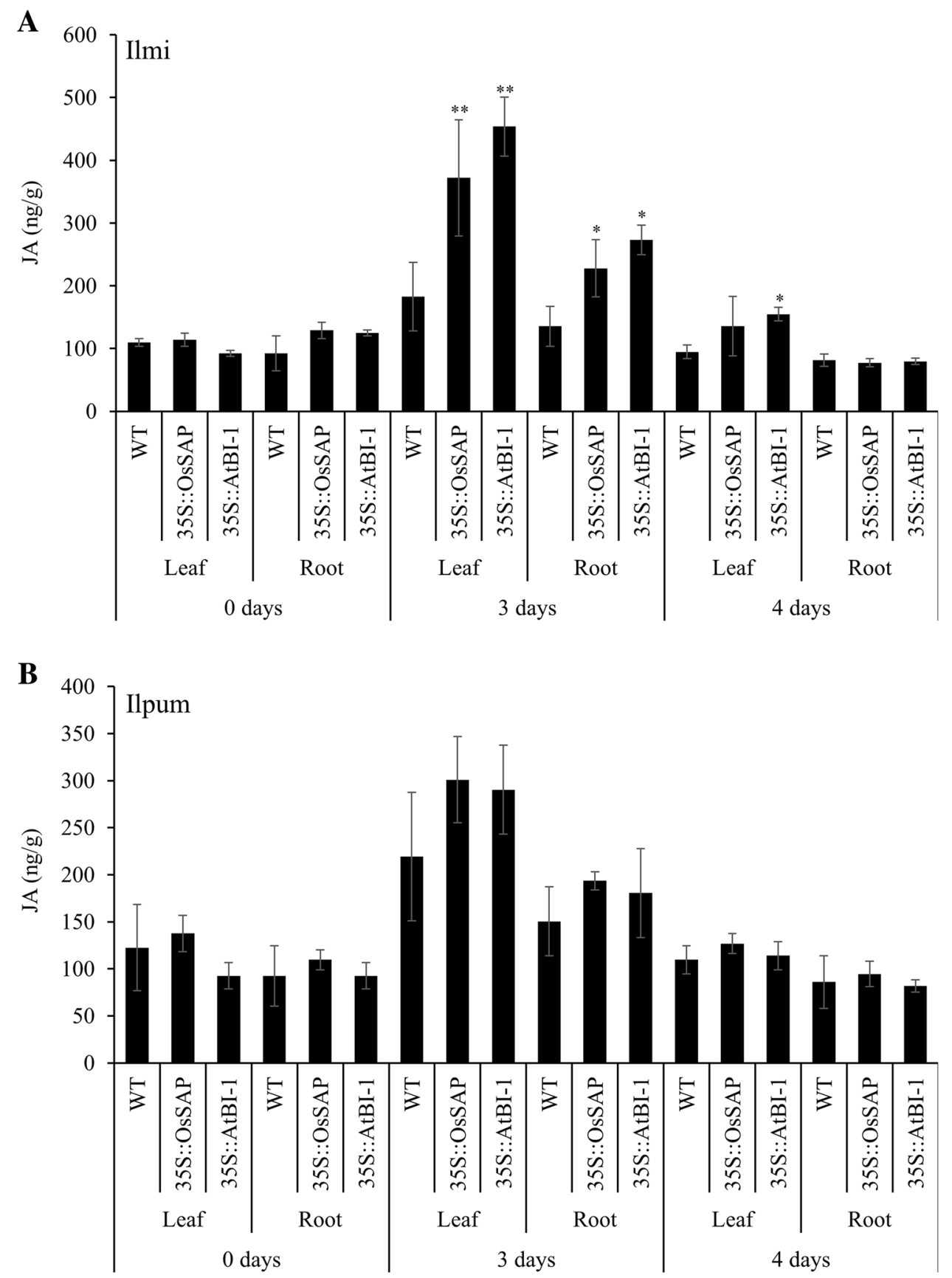

the over-expression of $O S S A P$ and AtBI- 1 plays a key role in drought stress regulation in rice.

In this study, the alteration of hormone level in transformants overexpressing the anti-apoptosis genes AtBI-1 and $O S S A P$ was also documented. Transformants harboring $A t B I-1$ and $O S S A P$ were used in the analysis. The alteration of hormone levels in rice represents the distinct plant responses toward abiotic stress due to different defence mechanisms. Phytohormones are in a prominent position, and play important regulatory roles in plant physiology that affects developmental processes during abiotic stresses
(Cheng et al. 2013; Browse 2009). Three hormones (ABA, $\mathrm{JA}$, and $\mathrm{GA}_{3}$ ) related with defence mechanisms during abiotic stress, particularly drought, were investigated. The role of ABA, JA, and SA as primary signals in the regulation of plant defence has been well established (Bari and Jones 2009; Pieterse et al. 2009). These hormones generate a signal transduction network that leads to a cascade of events responsible for the physiological adaptation of plants to stress. It was evident that the ABA level under drought stress increased in all leaf and root tissues in both OsSAP and AtBI-1 transformants. It is known that ABA 
Fig. 4 Gibberellic acid $\left(\mathrm{GA}_{3}\right)$ level in transformants compared with non-transformant controls under different drought conditions. Mean values \pm SE are given. $L L$, control Ilmi-leaf; $L R$, control Ilmi-leaf; $P L$, control Ilpum-leaf; $P R$, control Ilpum-root; $L O L, O S S A P$ Ilmi transformants-leaf; $L O R$, OsSAP Ilmi transformants-root; $P O L$, OsSAP Ilpum transformants-leaf; $P O R$, OsSAP Ilpum transformantsroot; $L A L, A t B I-1$ Ilmi transformants-leaf; LAR, AtBI-1 Ilmi transformants-root; $P A L$, AtBI-1 Ilpum transformantsleaf; PAR, AtBI-1 Ilpum transformants-root. *

**Significant at 5 and $1 \%$ levels, respectively
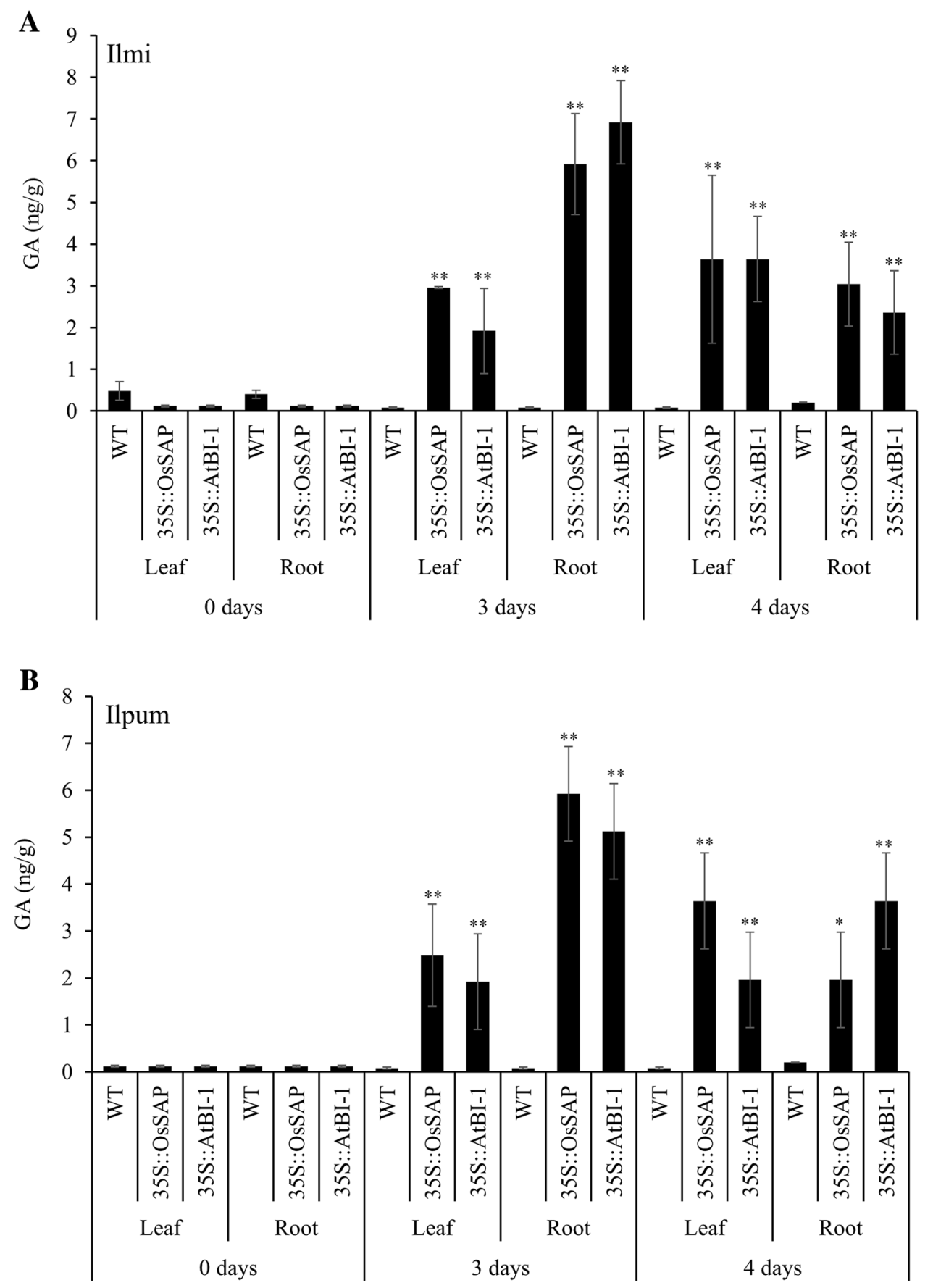

positively contributes toward adaptation to osmotic stress, a major component of several abiotic stresses (Kissoudis et al. 2014). Its role in defence-related responses has been well discussed in the reviews (Ton et al. 2009). ABA in plant cells is maintained dynamically during the processes of synthesis, degradation and transport, and hence by maintaining the endogenous ABA levels, plants maintain their developmental stages along with their response to stress conditions (Kissoudis et al. 2014). Stimulation of the anti-apoptotic proteins' production is also attributed to
ABA which minimizes the expression of these proteins (Scarfî et al. 2009). ABA plays an antagonistic role in response to Reactive Oxygen Species (ROS), including cell death, whereas ABA-treated cells maintain their ability to scavenge ROS (Wang et al. 2008). A similar protective role of ABA against cell death has been observed during androgenesis in developing barley anthers (Wang et al. 2008). It is now understandable that anti-apoptosis and ABA with $A t B I-1$ and $O s S A P$ overexpression could have connected pathways. 
Fig. 5 Zeatin level in transformants compared with controls under different drought conditions. Mean values $\pm \mathrm{SE}$ are given. $L L$, control Ilmi-leaf; $L R$, control Ilmi-leaf; $P L$, control Ilpum-leaf; $P R$, control Ilpum-root; $L O L, O S S A P$ Ilmi transformants-leaf; $L O R$, OSSAP Ilmi transformants-root; POL, OsSAP Ilpum

transformants-leaf; $P O R$,

OsSAP Ilpum transformantsroot; LAL, AtBI-1 Ilmi transformants-leaf; LAR, AtBI-1 Ilmi transformants-root; $P A L$, AtBI-1 Ilpum transformantsleaf; PAR, AtBI-1 Ilpum transformants-root. *, **Significant at 5 and $1 \%$ levels, respectively
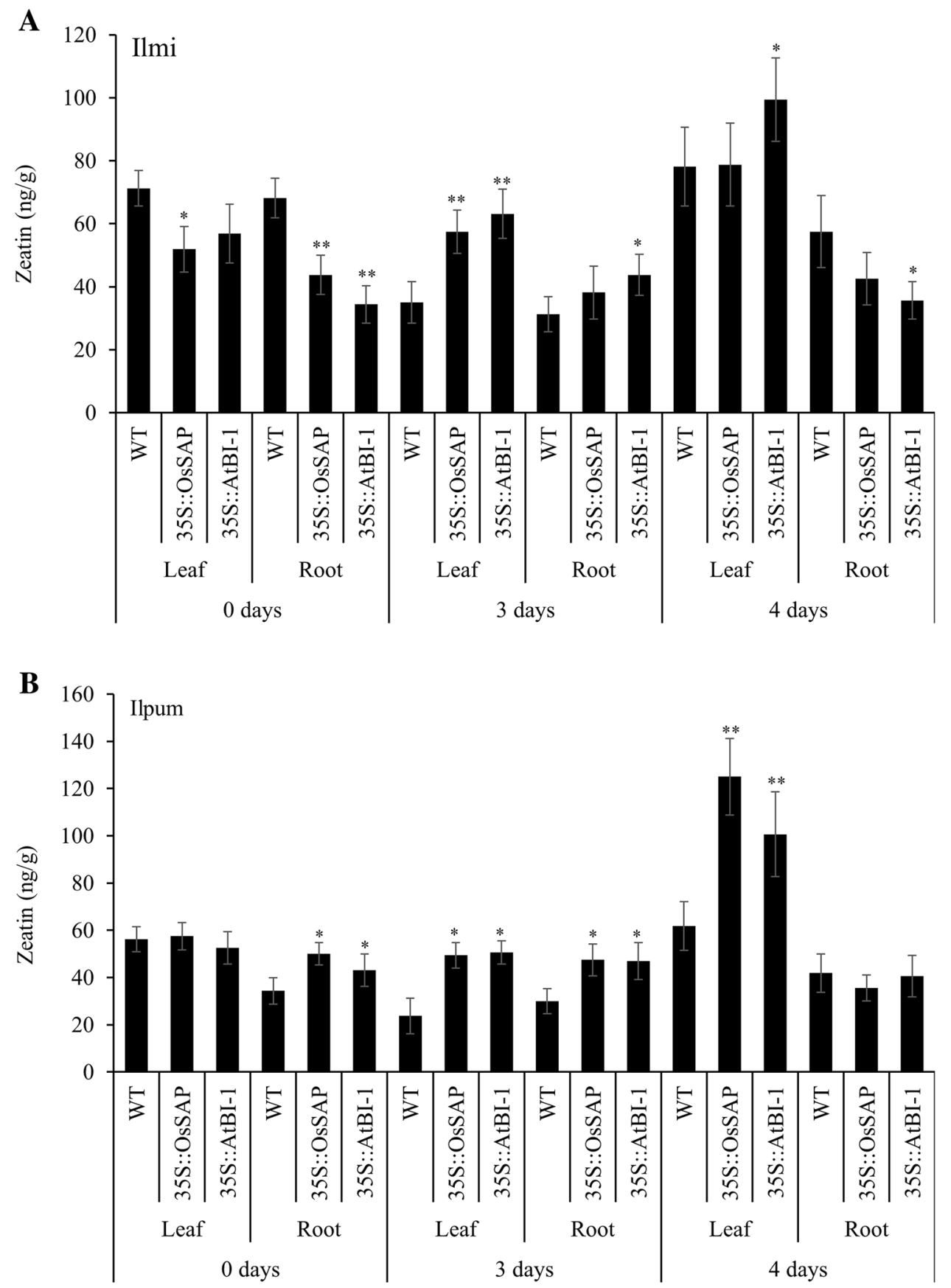

In the investigation of JA levels in the transformants overexpressing OsSAP and AtBI-1, and a control, high accumulations of JA under drought stress occurred in OsSAP and AtBI-1 transformants after moderate stress, but dramatically decreased after prolonged periods of stress. Jasmonic acid (JA) is a well-known signaling molecule in plant defence and stress responses (Hoeberichts and Woltering 2003). The participation of JA in response to abiotic stress, such as drought, has been reported in several species. Stimulated water stress increased endogenous content of JA, followed by the synthesis of jasmonate- induced proteins (Lehmann et al. 1995). It has been reported that tomato cultivars differ in salt tolerance due to different basal JA content. Steady-state amounts of JA and related compounds were higher with drought stress tolerance (Pedranzani et al. 2003). Furthermore, it was suggested that JA-related responses are directly associated with a reset, downstream of gene expression in the biosynthesis pathway (Thines et al. 2007). Together, these studies indicate that JA is an important component of a pathway that negatively regulates cell death and lesion formation. JA is believed to cause this effect by attenuating 
Fig. 6 Indole-3-carboxylic acid (ICA) level in transformants compared with non-

transformant controls under different drought conditions. Mean values \pm SE are given. $L L$, control Ilmi-leaf; $L R$, control Ilmi-leaf; $P L$, control Ilpum-leaf; $P R$, control Ilpumroot; $L O L$, OSSAP Ilmi transformants-leaf; $L O R$, OsSAP Ilmi transformants-root; $P O L, O s S A P$ Ilpum transformants-leaf; $P O R$, $O s S A P$ Ilpum transformantsroot; LAL, AtBI-1 Ilmi transformants-leaf; $L A R, A t B I-1$ Ilmi transformants-root; $P A L$, $A t B I-1$ Ilpum transformantsleaf; PAR, AtBI-1 Ilpum transformants-root. *,

**Significant at 5 and $1 \%$ levels, respectively
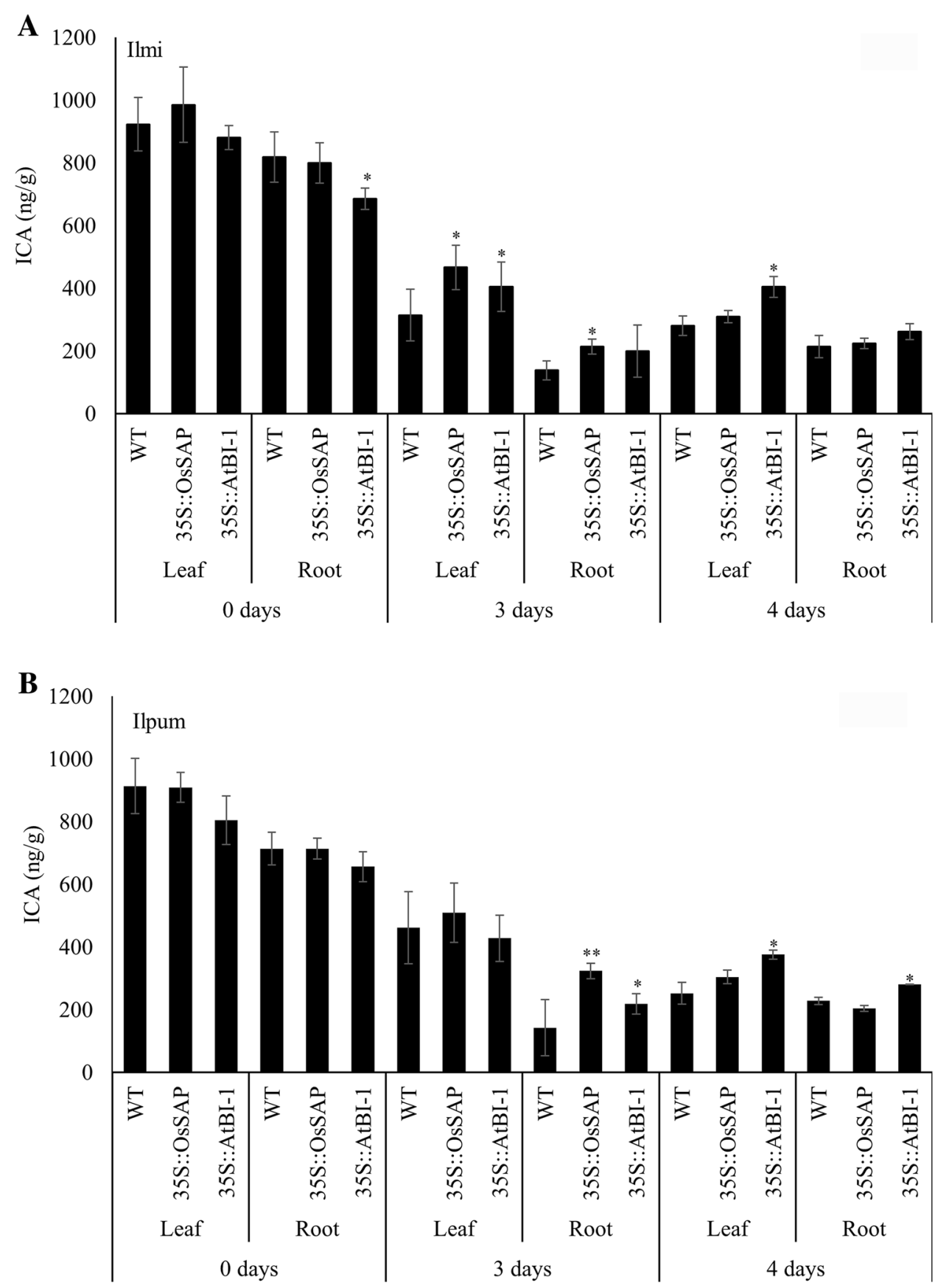

the O3-induced ROS production, as wounding or treatment of plants with JA has been shown to reduce O3-induced cell death and O3-induced ROS levels (Overmyer et al. 2000). However, the precise mechanisms by which JA signaling regulates anti-apoptosis remain to be elucidated. The response of altered JA levels in the OSSAP transformants during stress suggests the involvement of OSSAP in the JA physiological pathway. Under drought conditions, plants have developed complex mechanisms to perceive external signals, allowing them to optimally respond to the environment.
Some plant hormones, such as ABA, SA, and JA, regulate protective responses of plants against both abiotic and biotic stresses via synergistic and antagonistic actions, which are referred to as signaling crosstalk (Fujita et al. 2006). In Arabidopsis, it has been proposed that both JA and $\mathrm{ABA}$ act in the response to moderate drought $(30 \%$ field capacity; Aimar et al. 2011). JA and ABA might be connected in different stages of the response, driving an acclimation process during growth through an extensive genetic reprogramming to finally reach a new homeostasis (Harb et al. 2010). Overexpression of OsSAP and AtBI-1 
can improve the endogenous level of ABA and JA during the early stages of moderate drought. We suggest that these anti-apoptosis genes involved in increasing the endogenous ABA and JA levels could sufficiently stimulate the preparatory response needed for drought acclimation.

Investigation of $\mathrm{GA}_{3}$ level in transformed rice overexpressing $O S S A P$ and $A t B I-1$ under drought stress revealed high accumulations of this hormone; however, $\mathrm{GA}_{3}$ level was not detected or was at a very low level in the control. These results suggested that $\mathrm{GA}_{3}$ is involved only in the response to drought stress. Moreover, altered levels of $\mathrm{GA}_{3}$ due to the overexpression of anti-apoptosis genes $O S S A P$ and AtBI-1 confirmed their roles in the drought stress tolerance mechanism. In particular, convergence and functional modulation of $\mathrm{ABA}$ signaling by $\mathrm{GA}_{3}$ have a key regulatory function in the plant cellular network of stress and developmental signaling (Golldack et al. 2013). Recently, interesting evidence has been provided for a convergence and crosstalk of $\mathrm{GA}_{3}$ and ABA signaling with the developmental regulator JA in plant responses to drought (Wasternack and Hause 2013). It was also reported that exogenous application of $\mathrm{GA}_{3}$ can reduce cell damage and improve growth of maize (Zea mays) seedlings subjected to water stress (Wang et al. 2008). Therefore, we suggest that overexpression of anti-apoptosis genes $O S S A P$ and $A t B I-1$ increase the levels of endogenous $\mathrm{GA}_{3} \cdot \mathrm{GA}_{3}$ was demonstrated to be effective in alleviating cell damage of rice subjected to drought stress. Thus, the results imply that $O s S A P$ and $A t B I-1$ can increase $\mathrm{GA}_{3}$ level and might help to maintain cell membrane stability and increase tolerance to drought stress. Observation of cytokinin zeatin levels in transformed rice overexpressing OSSAP and AtBI1 under moderate drought stress revealed decreased accumulation levels of this hormone in all genotypes, and a slight increase after a prolonged period of stress. We found that zeatin levels were higher in transformant plants compared to those of control plants under drought stress. Decreased cytokinin content in response to drought stress has been observed and leaf zeatin concentration declined under osmotic stress in the tomato (Solanum lycopersicum; Walker and Dumbroff 1981). This also indicated that the relationship between zeatin and $O S S A P$ and AtBI-1 overexpression with anti-apoptosis could have connected pathways. ICA accumulation was different in leaf and root tissues. Drought stress dramatically decreased ICA levels, but no difference between control and transformants plants was observed. However, auxin is involved in the attenuation of defense responses in plants. Conversely, blocking auxin responses increases resistance in plants (Bari and Jones 2009). In summary, this finding suggests that these hormones and response to abiotic stress in rice are not related to each other. Although similar pattern is observed for many components of the pathway along with a number

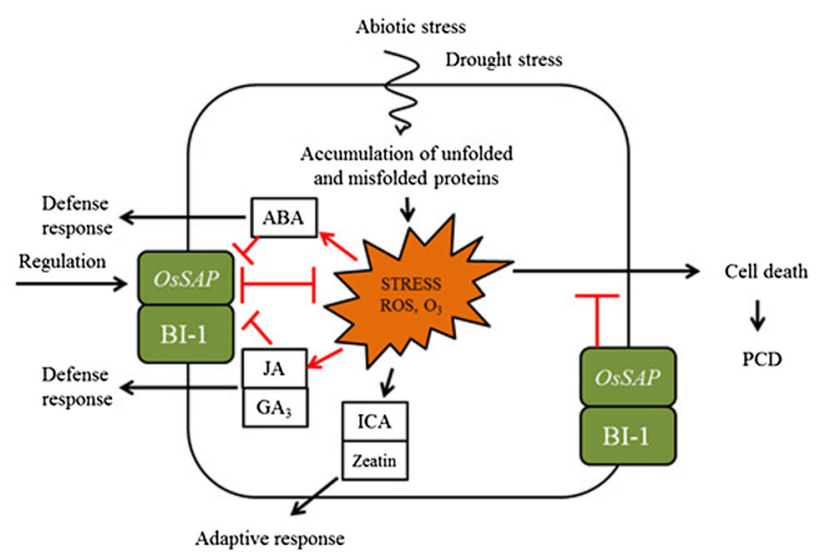

Fig. 7 Proposed model on crosstalk of abscisic acid (ABA), gibberellic acid $\left(\mathrm{GA}_{3}\right)$, and jasmonate (JA) signaling in cellular response of plants to drought, elicited by $O S S A P$ and $A t B I-1$ genes

of genes induced by the abiotic stress, it is worth to be noted that the expression pattern of a specific gene varies according to the time and level of its expression under specific experimental conditions in different tissues. The variation that occurs can be attributed to the variation in treatments, their severity and duration. The crosstalk and regulatory mechanisms of different pathways in the plants can also be affected by their hormonal status under variable stress conditions. However, the plant hormones' regulatory network and its signaling under abiotic stress are yet to be unveiled. Also the stress-related genes involved in hormone signaling are yet to be discovered. Rice transformants overexpressing the anti-apoptosis genes under drought stress having changes in endogenous hormone levels would allow better understanding of the response of plants to drought stress and help develop drought-tolerant crops.

\section{Proposed model on crosstalk of hormonal signaling in plants}

In this study, anti-apoptosis genes $O S S A P$ and $A t B I-1$ were demonstrated to induce different patterns of hormone levels, indicating that these genes and plant hormone pathways are mechanistically connected in the response of plants to abiotic stress, in particular drought stress. Our hypothesis linking $O S S A P$ and $A t B I-1$ genes with hormone signaling in rice plants is schematically shown in Fig. 7.

\section{Conclusion}

OsSAP, an anti-apoptotic activator, modulates a diverse plant hormonal signaling network primarily including antagonistic mode of ABA, JA and $\mathrm{GA}_{3}$. Particularly, $\mathrm{GA}_{3}$ 
exhibited retarded accumulation kinetics during early stage of drought stress compared to other hormones. Differential accumulation and kinetics mode of plant hormones mediated by the overexpression of $O s S A P$ and $A t B I-1$, a homolog of the human Bax inhibitor-1 in Arabidopsis, would pave a new way to understanding the defense signaling in response to diverse stress condition.

Acknowledgements This research was supported by Kyungpook National University Research Fund, 2016.

\section{Compliance with ethical standards}

Conflict of interest None declared.

Open Access This article is distributed under the terms of the Creative Commons Attribution 4.0 International License (http:// creativecommons.org/licenses/by/4.0/), which permits unrestricted use, distribution, and reproduction in any medium, provided you give appropriate credit to the original author(s) and the source, provide a link to the Creative Commons license, and indicate if changes were made.

\section{References}

Aimar D, Calafat M, Andrade AM, Carassay L, Abdala GI, Molas ML (2011) Drought Tolerance and Stress Hormones: From Model Organisms to Forage Crops. In: Vasanthaiah H (ed) Plants and environment. ISBN: 978-953-307-779-6

Aloni R, Aloni E, Langhans M, Ullrich CI (2006) Role of cytokinin and auxin in shaping root architecture: regulating vascular differentiation, lateral root initiation, root apical dominance and root gravitropism. Ann Bot 97:883-893

Arasimowicz-Jelonek M, Floryszak-Wieczorek J, Deckert J, Rucinska-Sobkowiak R, Gzyl J, Pawlak-Sprada S, Abramowski D, Jelonek T, Gwozdz EA (2012) Nitric oxide implication in cadmium-induced programmed cell death in roots and signaling response of yellow lupine plants. Plant Physiol Bioch $58: 124-134$

Bari R, Jones JDG (2009) Role of hormones in plant defense responses. Plant Mol Biol 69:473-488

Biswas MS, Mano J (2015) Lipid peroxide-derived short-chain carbonyls mediate hydrogen peroxide-induced and salt-induced programmed cell death in plants. Plant Physiol 168:885-898

Boyer JS (1982) Plant productivity and environment. Science 218:443-448

Browse J (2009) Jasmonate passes muster: a receptor and targets for the defense hormone. Annu Rev Plant Biol 60:183-205

Cheng SJ, Liu RY, Gallie DR (2013) The unique evolution of the programmed cell death 4 protein in plants. BMC Evol Biol 13:199

Davies PJ (1987) The plant hormones: their nature, occurrence, and functions in the plant hormones their role in plant growth and development. Springer, The Netherlands, pp 1-11 [ISBN: 978-90-247-3498-6 (Print); ISBN: 978-94-009-3585-3 (Online)]

Davies PJ (1995) The plant hormones: their nature, occurrence and functions. In: Davies PJ (ed) Plant Hormones Physiology, Biochemistry and Molecular Biology. Kluwer Academic Publishers, Dordrecht, The Netherlands, pp 1-12

De la Rosa M, Gonzalez-Arzola K, Martinez-Fabregas J, DiazQuintana A, Diaz-Moreno I (2015) A common cytochrome c-centred signalosome for programmed cell death in humans and plants. FASEB J 29:569

Del Duca S, Serafini-Fracassini D, Cai G (2014) Senescence and programmed cell death in plants: polyamine action mediated by transglutaminase. Front Plant Sci 5:98 (Article 120)

Eichmann R, Schultheiss H, Kogel KH, Hückelhoven R (2004) The barley apoptosis suppressor homologue BAX inhibitor-1 compromises nonhost penetration resistance of barley to the inappropriate pathogen Blumeria graminis $f$. sp. tritici. Mol Plant Microbe Interact 17:484-490

Flowers TJ (2004) Improving crop salt tolerance. J Exp Bot 55:307-319

Foyer C. (2007a) Cellular redox metabolism, programmed cell death and defence responses in plants. Free Radic Res 41:S12-S13

Foyer C (2007b) Redox metabolism in plants and its role in programmed cell death and senescence. Comp Biochem Phys A 146:S53-S53

Franklin-Tong VE, Gourlay CW (2008) A role for actin in regulating apoptosis/programmed cell death: evidence spanning yeast, plants and animals. Biochem J 413:389-404

Fujita M, Fujita Y, Noutoshi Y, Takahashi F, Narusaka Y, Yamaguchi-Shinozaki K, Shinozaki K (2006) Crosstalk between abiotic and biotic stress responses: A current view from the points of convergence in the stress signaling networks. Curr Opin Plant Biol 9:436-442

Gadjev I, Stone JM, Gechev TS (2008) Programmed cell death in plants: new insights into redox regulation and the role of hydrogen peroxide. Int Rev Cel Mol Bio 270:87-144

Godfray HCJ, Beddington JR, Crute IR, Haddad L, Lawrence D, Muir JF, Pretty J, Robinson S, Thomas SM, Toulmin C (2010) Food security: the challenge of feeding 9 billion people. Science 327:812-818

Golldack D, Li C, Mohan H, Probst N (2013) Gibberellins and abscisic acid signal crosstalk: living and developing under unfavorable conditions. Plant Cell Rep 32:1007-1016

Gonzalez-Arzola K, Moreno-Beltran B, Martinez-Fabregas J, ElenaReal CA, Diaz-Quintana A, Diaz-Moreno I, De la Rosa MA (2015) A common role for cytochrome c in programmed cell death in humans and plants. Protein Sci 24:259-260

Gross A, Jockel J, Wei MC, Korsmeyer SJ (1998) Enforced dimerization of BAX results in its translocation, mitochondrial dysfunction and apoptosis. EMBO J 17:3878-3885

Hanada M, Aime-Sempe C, Sato T, Reed JC (1995) Structurefunction analysis of $\mathrm{Bcl}-2$ protein. Identification of conserved domains important for homodimerization with $\mathrm{Bcl}-2$ and heterodimerization with Bax. J Biol Chem 270:11962-11969

Harb A, Krishnan A, Ambavaram MM, Pereira A (2010) Molecular and physiological analysis of drought stress in Arabidopsis reveals early responses leading to acclimation in plant growth. Plant Physiol 154:1254-1271

Hoeberichts FA, Woltering EJ (2003) Multiple mediators of plant programmed cell death: interplay of conserved cell death mechanisms and plant-specific regulators. Bioessays 25:47-57

Hsu YT, Wolter KG, Youle RJ (1997) Cytosol-to-membrane redistribution of Bax and Bcl-XL during apoptosis. Proc Natl Acad Sci USA 94:3668-3672

Huckelhoven R (2004) BAX Inhibitor-1, an ancient cell death suppressor in animals and plants with prokaryotic relatives. Apoptosis 9:299-307

Isbat M, Zeba N, Kim SR, Hong CB (2009) A BAX inhibitor-1 gene in Capsicum annuum is induced under various abiotic stresses and endows multi-tolerance in transgenic tobacco. J Plant Physiol 166:1685-1693

Kacprzyk J, Daly CT, McCabe PF (2011) The botanical dance of death: programmed cell death in plants. Adv Bot Res 60:169-261 
Kang CH, Jung WY, Kang YH, Kim JY, Kim DG, Jeong JC, Baek DW, Jin JB, Lee JY, Kim MO, Chung WS, Mengiste T, Koiwa H, Kwak SS, Bahk JD, Lee SY, Nam JS, Yun DJ, Cho MJ (2006) AtBAG6, a novel calmodulin-binding protein, induces programmed cell death in yeast and plants. Cell Death Differ 13:84-95

Kawai-Yamada M, Jin L, Yoshinaga K, Hirata A, Uchimiya H (2001) Mammalian Bax-induced plant cell death can be down-regulated by overexpression of Arabidopsis Bax Inhibitor-1 (AtBI-1). Proc Natl Acad Sci USA 98:12295-12300

Kawai-Yamada M, Ohori Y, Uchimiya H (2004) Dissection of Arabidopsis Bax inhibitor-1 suppressing Bax-, hydrogen peroxide-, and salicylic acid-induced cell death. Plant Cell 16:21-32

Kawai-Yamada M, Saito Y, Jin LH, Ogawa T, Kim KM, Yu LH, Tone Y, Hirata A, Umeda M, Uchimiya H (2005a) A novel Arabidopsis gene causes Bax-like lethality in Saccharomyces cerevisiae. J Biol Chem 280:39468-39473

Kawai-Yamada M, Yoshinaga K, Ogawa T, Ihara-Ohori Y, Uchimiya $\mathrm{H}$ (2005b) Oxidative stress and plant cell death suppressors. Plant Biotechnol 22:419-422

Kim YJ, Park CJ, Ham BK, Paek KH (2009) Involvement of the fasassociated factor 1 ortholog, CaFAF1, in regulating programmed cell death in plants. J Plant Biol 52:125-134

Kissoudis C, Wiel VDC, Visser RGF, Linden VDG (2014) Enhancing crop resilience to combined abiotic and biotic stress through the dissection of physiological and molecular crosstalk. Front Plant Sci 5:207

Kroemer G (1997) The proto-oncogene $\mathrm{Bcl}-2$ and its role in regulating apoptosis. Nat Med 3:614-620

Kunikowska A, Byczkowska A, Doniak M, Kazmierczak A (2013) Cytokinins resume: their signaling and role in programmed cell death in plants. Plant Cell Rep 32:771-780

Lacomme C, Cruz SS (1999) Bax-induced cell death in tobacco is similar to the hypersensitive response. Proc Natl Acad Sci USA 96:7956-7961

Lehmann J, Atzorn R, Brückner C, Reinbothe S, Leopold J, Wasternack C, Parthier B (1995) Accumulation of Jasmonate, abscisic acid, specific transcripts and proteins in osmotically stressed barley leaf segments. Planta 197:156-162

Li J, Wang DY, Li Q, Xu YJ, Cui KM, Zhu YX (2004) PPF1 inhibits programmed cell death in apical meristems of both G2 pea transgenic Arabidopsis plants possibly by delaying cytosolic $\mathrm{Ca}^{2+}$ elevation. Cell Calcium 35:71-77

Locato V, de Pinto MC, Gadaleta C, De Gara L (2009) Ascorbate metabolism as critical point for the activation of programmed cell death in plants. Free Radic Res 43:77

Ma Y, Berkowitz GA (2011) Danger at your door: pathogen signals and programmed cell death in plants. New Phytol 192:1-3

Nechushtan A, Smith CL, Hsu YT, Youle RJ (1999) Conformation of the Bax C-terminus regulates subcellular location and cell death. EMBO J 18:2330-2341

Oltvai ZN, Milliman CL, Korsmeyer SJ (1993) Bcl-2 Heterodimerizes in-Vivo with a conserved homolog, Bax, that accelerates programmed cell-death. Cell 74:609-619

Overmyer K, Tuominen H, Kettunen R, Betz C, Langebartels C, Sandermann H Jr, Kangasjärvi J (2000) Ozone-sensitive arabidopsis rcd1 mutant reveals opposite roles for ethylene and jasmonate signaling pathways in regulating superoxide-dependent cell death. Plant Cell 12:1849-1862

Pedranzani H, Racagni G, Alemano S, Miersch O, Ramírez I, Peña Cortés H, Machado-Domenech E, Abdala G (2003) Salt tolerant tomato plants show increased levels of jasmonic acid. Plant Growth Regul 41:149-158

Petrov V, Hille J, Mueller-Roeber B, Gechev TS (2015) ROSmediated abiotic stress-induced programmed cell death in plants. Front Plant Sci 6:69 (Article 69)
Pieterse CMJ, Leon-Reyes A, Van der Ent S, Van Wees SCM (2009) Networking by small-molecule hormones in plant immunity. Nat Chem Biol 5:308-316

Piszczek E, Gutman W (2007) Caspase-like proteases and their role in programmed cell death in plants. Acta Physiol Plant 29:391-398

Rantong G, Gunawardena AHLAN (2015) Programmed cell death: genes involved in signaling, regulation, and execution in plants and animals. Botany 93:193-210

Reape TJ, Molony EM, McCabe PF (2008) Programmed cell death in plants: distinguishing between different modes. J Exp Bot 59:435-444

Samuilov VD, Kiselevsky DB, Nesov AV, Dzyubinskaya EV, Vasil'ev LA, Samuilov FD (2014) Programmed cell death in plants under anaerobic conditions: effect of $\mathrm{Ag}+$. Russ J Plant Physiol 61:590-597

Sanchez P, Zabala MD, Grant M (2000) AtBI-1, a plant homologue of Bax Inhibitor-1, suppresses Bax-induced cell death in yeast and is rapidly upregulated during wounding and pathogen challenge. Plant J 21:393-399

Sato T, Hanada M, Bodrug S, Irie S, Iwama N, Boise LH, Thompson CB, Golemis E, Fong L, Wang H-G (1994) Interactions among members of the Bcl-2 protein family analyzed with a yeast twohybrid system. Proc Natl Acad Sci 91:9238-9242

Scarfî S, Fresia C, Ferraris C, Bruzzone S, Fruscione F, Usai C, Benvenuto F, Magnone M, Podestà M, Sturla L, Guida L, Albanesi E, Damonte G, Salis A, De Flora A, Zocchi E (2009) The plant hormone abscisic acid stimulates the proliferation of human hemopoietic progenitors through the second messenger cyclic ADP-ribose. Stem Cells 10:2469-2477

Shi Y, Chen JJ, Weng CJ, Chen R, Zheng YH, Chen Q, Tang $\mathrm{H}$ (2003) Identification of the protein-protein contact site and interaction mode of human VDAC1 with Bcl-2 family proteins. Biochem Biophys Res Commun 305:989-996

Siczek L, Mostowska A (2012) Characteristics and Function of "Plant Caspases" during Programmed Cell Death in Plants. Postepy Biol Komorki 39:159-172

Solovieva AD, Frolova OY, Solovyev AG, Morozov SY, Zamyatnin AA (2013) Effect of mitochondria-targeted antioxidant SkQ1 on programmed cell death induced by viral proteins in tobacco plants. Biochemistry (Moscow) 78:1006-1012

Tester M, Langridge P (2010) Breeding technologies to increase crop production in a changing world. Science $327: 818-822$

Tewari RK, Bachmann G, Hadacek F (2015) Iron in complex with the alleged phytosiderophore 8-hydroxyquinoline induces functional iron deficiency and non-autolytic programmed cell death in rapeseed plants. Environ Exp Bot 109:151-160

Thines B, Katsir L, Melotto M, Niu Y, Mandaokar A, Liu G, Nomura K, He SY, Howe GA, Browse J (2007) JAZ repressor proteins are targets of the SCF (COI1) complex during jasmonate signalling. Nature 448:661-665

Ton J, Flors V, Mauch-Mani B (2009) The multifaceted role of ABA in disease resistance. Trends Plant Sci 14:310-317

Trobacher CP (2009) Ethylene and programmed cell death in plants. Botany 87:757-769

Ubaidillah M, Safitri FA, Lee S, Park GH, Kim KM (2015) Alteration of plant hormones in transgenic rice (Oryza sativa L.) by overexpression of anti-apoptosis genes during salinity stress. J Plant Biotechnol 42:168-179

Vasil'ev LA, Dzyubinskaya EV, Zinovkin RA, Kiselevsky DB, Lobysheva NV, Samuilov VD (2009) Chitosan-induced programmed cell death in plants. Biochemistry (Moscow) 74:1035-1043

Walker MA, Dumbroff EB (1981) Effects of salt stress on abscisicacid and cytokinin levels in tomato. $\mathrm{Z}$ Pflanzenphysiol $101: 461-470$ 
Wang C, Yang A, Yin H, Zhang J (2008) Influence of water stress on endogenous hormone contents and cell damage of maize seedlings. J Integr Plant Biol 50:427-434

Wang JH, Bayles KW (2013) Programmed cell death in plants: lessons from bacteria? Trends Plant Sci 18:133-139

Wang W, Vinocur B, Shoseyov O, Altman A (2001) Biotechnology of plant osmotic stress tolerance physiological and molecular considerations. IV Int Symp Vitro Cult Hortic Breed 560:285-292

Wasternack C, Hause B (2013) Jasmonates:biosynthesis, perception, signal transduction and action in plant stress response, growth and development. An update to the 2007 review in Annals of Botany. Ann Bot 111:1021-1058

Watanabe N, Lam E (2008) BAX inhibitor-1 modulates endoplasmic reticulum stress-mediated programmed cell death in Arabidopsis. J Biol Chem 283:3200-3210
Weng CJ, Li Y, Xu D, Shi Y, Tang H (2005) Specific cleavage of Mcl-1 by caspase-3 in tumor necrosis factor-related apoptosisinducing ligand (TRAIL)-induced apoptosis in Jurkat leukemia T cells. J Biol Chem 280:10491-10500

Yang ZT, Wang MJ, Sun L, Lu SJ, Bi DL, Sun L, Song ZT, Zhang SS, Zhou SF, Liu JX (2014) The membrane-associated transcription factor NAC089 controls ER-Stress-Induced programmed cell death in Plants. PLoS Genet 10(3):e1004243

Zhang JH, Jia WS, Yang JC, Ismail AM (2006) Role of ABA in integrating plant responses to drought and salt stresses. Field Crops Res 97:111-119

Zhou Y, Wang CY, Ge H, Hoeberichts FA, Visser PB (2005) Programmed cell death in relation to petal senescence in ornamental plants. J Integr Plant Biol 47:641-650 